\title{
Spaces of Intercommunal Musical Relations in Ottoman Istanbul
}

\author{
Panagiotis C. Poulos*
}

\section{Mekân}

Space holds an important position in the recent critical historiography of Ottoman/Turkish music. Whether in the narrow sense of the physical setting that hosted musical performance, or in a broader and more symbolic sense that includes the evocation of place as an important identity marker of musicians and of musical styles, ${ }^{1}$ the notion of space underlines the discussion over the definition of Ottoman/Turkish music and of its historical development. Cem Behar in his influential essay on this topic entitled "Bir Oda Müziği: Geleneksel Osmanll/Türk Musıkisi” ${ }^{2}$ offers a historical overview of the performance settings of Ottoman/Turkish music. Behar brings to the fore the spatial dimension and examines the interrelation between space and the cultural and technical elements of music. Drawing from this analysis he argues towards the incompatibility of certain republican practices, such as choral performance. The apt and slightly provocative title of Behar's essay foregrounds the convivial and intimate form of communication among musicians and listeners, ${ }^{3}$ which first and foremost is a deeply rooted cultural feature in the musical and literary tradition of the Ottomans and the Islamic Middle East in general. ${ }^{4}$

The spatial dimension is also crucial in setting the internal boundaries of the cultural and social hierarchies of Ottoman/Turkish music. The distinction between the court and the outer domain, at least in the earlier period, shows genre subdivisions based on patronage, the professionalism of musicians, and the background of audiences. For instance, the domain of the Islamic mystical orders (tarikat), which devotedly supported musical transmission and creativity, was primarily laid outside of the court yet held constant and stable ties with the circle of courtiers that transcended the aforementioned distinction. ${ }^{5}$ The mutability of these boundaries is further demonstrated by the shift in the eighteenth century of musical patronage and of the overall activity from the court to the city. The broadening of social boundaries among musical participants behind this shift went hand in hand with a renewal of the musical geography in prominent urban centers, such as Istanbul, through the emergence of spaces hosting new modes of sociality ${ }^{6}$ where music was an important component. This phenomenon is reflected in recent historiography on Ottoman music and has prompted the need for redefining this musical genre in terms of a 'city music' or an 'urban music.'

Evidently, music is bound to an array of 'exterior' spatiality (e.g. the court, the city, the Sufi convent, etc.) and to the social dimension, ${ }^{8}$ making it rather difficult to think about each of them separately. This interrelationship is dynamic, which consequently means that space affects and is affected by the musicians and their musical performances. As Georgina Born

\footnotetext{
* National and Kapodistrian University of Athens, ppoulos@music.uoa.gr

1 Walter Feldman, Music of the Ottoman Court: Makam, Composition and the Early Ottoman Instrumental Repertoire, Intercultural Music Studies 10 (Berlin: VWB- Verlag für Wissenschaft und Bildung, 1996), 52-54.

2 This essay has been republished, see Cem Behar, “Müziğin Mekân Boyutu (Bir Oda Müziği: Geleneksel / Osmanlı Türk Musıkisi)," in Osmanlı Türk Mustkisinin Kısa Tarihi, ed. Cem Behar (Istanbul: YKY, 2015), 43-66.

3 lbid., 43

4 Halil İnalcık, Has-bağcede 'Ays u Tarab. Nedîmler, Sâîrler, Mutrîbler (Istanbul: Türkiye İs Bankası Kültür Yayınları), 281-292.

5 Feldman, Music of the Ottoman Court, 93-102. For the participation of Mevlevi musicians in the Ottoman Court, see in particular, 93-94.

6 Shirine Hamadeh, The City's Pleasures: Istanbul in the Eighteenth Century (Seattle: University of Washington Press, 2004), 11, 56, 75.

7 Cem Behar, Şeyhülislam'ın Müziği. 18. Yüzyllda Osmanll/Türk Mustkisi ve Şeyhülislâm Esad Efendinin Atrabül-âsârı (Istanbul: YKY, 2010), 172; Bülent Aksoy, Geçmişin Musıki Mirasina Bakışlar (Istanbul: Pan, 2008), 32-33.

8 Georgina Born, "Introduction - Music, Sound and Space. Transformations of Public and Private Experience," Music Sound and Space: Transformations of Public and Private Experience, ed. Georgina Born (Cambridge: Cambridge University Press, 2013), 16, 17.
} 
182 states regarding the relation between space and the creative processes in music: "Space is both produced and transformed." By employing this mode of inquiry on the relation between music and space, this article aims to examine the intercommunal interaction and music making within the Ottoman/Turkish musical tradition. More specifically, the aim of this analysis is on the one hand to highlight the intercommunal musical interactions and/or exclusions shaped in the form of collective networks and an individual's itinerary within the shifting urban environment of Istanbul. On the other hand, this article aims to explore the role of space both as a physical and an imaginary component of Istanbul's musical history in shaping and sustaining the abovementioned cultural pluralism.

\section{Music between and within Communities}

The position and role of the musicians who formed the various non-Muslim communities of the Ottoman Empire in the history of Ottoman/Turkish urban music has lately attracted increasing scholarly attention..$^{10}$ According to the current historiographical scheme, nonMuslim musicians appeared in the Ottoman court in the seventeenth century, primarily as instrumentalists and then as composers of instrumental repertoire. In the middle of the eighteenth century, non-Muslim musicians entered the domain of vocal composition. ${ }^{11}$ This shift should not be considered independently from the abovementioned 'opening up' that overall characterizes Ottoman society in the eighteenth-century urban context..$^{12}$ The widening of social relations during the 'middle period' (1600-180o) allowed non-Muslim subjects of the empire a greater engagement in public affairs, particularly within the urban environment of major cities like Istanbul. While the origins of this process is situated earlier on, it is in the eighteenth century that this interaction became dynamic, and its effects were evident in the development of both the central urban musical genre and the various community-bounded genres of distinct syncretic character (e.g. maftirim). ${ }^{13}$ With the popularization of vocal repertoire in the early nineteenth century, there was an increase in the representation of non-Muslim composers in the output of vocal composition. However, as suggested in recent research, it is doubtful whether this phenomenon is statistically grounded and, more importantly, whether it implies that intercommunal musical relations were further intensified. ${ }^{14}$ This topic will be discussed further on in more detail.

In spatial terms, this historiographical scheme follows the wider trajectory of Ottoman/ Turkish music from the court to the city. ${ }^{15}$ It is rather telling of this trend that a significant part of musical syncretism took place in Sufi convents located in the city and concerned circles of community musicians, like the cantors of the Greek Orthodox and Armenian churches and the synagogues. One should add to that the private musical patronage seen in houses and mansions, musical taverns (meyhane) and nightclubs, as well as the newly emerged public spaces or better open-air spaces that hosted new forms of sociality involving music, like picnic areas and promenades (mesire). ${ }^{16}$

The intensification of intercommunal relationships observed in the eighteenth century is

9 Born, Music Sound and Space, 20.

10 A detailed analysis of the importance of the subject as well as a detailed review of intercommunal musical relations in Ottoman/Turkish music is beyond the scope of this article. For a brief summary of recent publications and research topics, see Panagiotis C. Poulos, "Greek Orthodox Music in Ottoman Istanbul: Nation and Community in the Era of Reform, by Merih Erol," Middle Eastern Studies 53, no. 4 (2017): 673-675. In addition, for a critical discussion of the construction of the category 'minority musician' in modern Turkish historiography on Ottoman music, see Panagiotis C. Poulos, "Greeks and Turks Meet the Rum: Making Sense of the Sounds of 'Old Istanbul”" in When Greeks and Turks Meet: Interdisciplinary Perspectives on the Relationship since 1923, ed. Vally Lytra (Aldershot: Ashgate, 2014), 88-91.

11 Feldman, Music in the Ottoman Court, 48-49.

12 Rifa'at 'Ali Abou-El-Haj, Formation of the Modern State: The Ottoman Empire, Sixteenth to Eighteenth Centuries (Syracuse: Syracuse University Press, 2005), 86-92.

13 Maureen Jackson, Mixing Musics: Turkish Jewry and the Urban Landscape of a Sacred Song (Stanford: Stanford University Press, 2013). For various recent contributions on the study of the 'Phanariot song' tradition see in particular, Julia Hatzipanagioti-Sangmeister et al.,

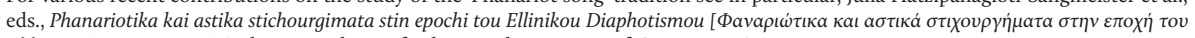

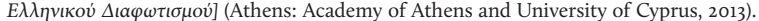

14 Jacob Olley, Writing Music in Nineteenth-Century Istanbul. Ottoman Armenians and the Invention of the Hampartzum Notation (PhD diss., King's College London, 2017), 181.

15 Bülent Aksoy, "Tanzimat'tan Cumhuriyet'e Musıki ve Batılılaşma," in Tanzimat'tan Cumhuriyet'e Türkiye Ansiklopedisi, ed. Murat Belge and Fahri Aral (Istanbul: iletişim Yayınları, 1985), 122.

16 Onur Öner, "A Collective Biography Study of Musicians: Patterns, Networks and Music as a "Profession" in the Late Ottoman Era and the Early Republican Years in Istanbul" (PhD diss., Istanbul Sehir University, 2019), 131-333. For the general picture of the lstanbul's urban transformation in the eighteenth century, see also Hamadeh, The City's Pleasures. 
certainly more easily traceable within the circles of literate elites. Such groups would include high-ranking Muslim officials, community dignitaries with an amateur interest in music, and learned community musicians, such as church cantors. However, this prominence, reinforced by the sparseness of relevant sources, possibly overshadows parallel cross-faith and crosscultural interactions that operated on a different social level. A telling example from the earlier stages in the history of intercommunal relationships is the story behind some of the non-Turkish folk song material included in the seventeenth-century musical mecmua (Turc 292) compiled by the celebrated Pole held captive by the Ottomans, Wojciech Bobowski/Ali Ufkî. Without a doubt, Ali Ufkî was a dynamic intermediary figure whose role as a 'cultural broker' between various individuals and their social and intellectual environments has been discussed in the current literature. However, when it comes to his interaction with nonMuslim subjects of the Ottoman Empire, these are again situated within the literate social circles of Istanbul. His relations with Panayiotis Nikousios, the Rum interpreter of the Sublime Porte who offered his services from 1661 until his death in 1673 , is a representative example. ${ }^{17}$

A closer look at the content and the palaeographic evidence of the two Greek folk songs that were recorded in the abovementioned musical collection suggests that the non-Muslim environment with which Ali Ufkî was acquainted was socially diverse with distinct internal stratification..$^{18}$ In brief, the first folk song is a love song, and the second is a song about a wedding feast among mice and bugs. The mocking character of the second song and the use of obscene and vulgar language points to the tradition of carnival folk songs sung during the Triodion, the pre-Lenten period that reaches its peak at the Carnival (Apokreo) festivities, forty days before Greek Orthodox Easter. Based on linguistic evidence, the songs come from two different regions and consequently from two different sources. The first one can be located in eastern Thrace and the wider area around Istanbul. The second belongs to the Greek northern dialect group and could be from various places in northern mainland Greece. What further complicates the question of the sources of these folk songs is a note in Italian on the last line of the first folk song: "marko di loma imita li gatti quando dicono mau" ["Marko from Loma imitates the cat's meow"]. If this is read correctly, then it refers to a certain Marko from Loma, which can be identified either as the kaza (Bicaj) in the Vilayet of Kosovo or alternatively as a port city on the Danube in northwest Bulgaria. ${ }^{19}$

The above features weaken the possibility that Ali Ufkîs sources directly belonged to the literate elites of the Greek Orthodox community. The obvious questions that emerge are who Ali Ufkî's informants were and how and where they met. At this point we can only make guesses-one is that based on the early dating of the manuscript, Ali Ufkîs encounter with his Greek speaking informants was situated in the Enderun, and therefore we are possibly dealing with converts (içoğlan) from Greek-speaking areas in the Balkans. A less possible guess could be that Ali Ufkîs informants were acquaintances from the city through merchant networks. ${ }^{20}$ Whether this intercultural musical encounter between the Pole convert Wojciech Bobowski and his Greek-speaking informants taking place in the Enderun or outside of it is not certain. Yet it seems that the Ottoman capital, Istanbul, as early as the mid-seventeenth century had developed those mechanisms that allowed a certain degree of social and ethno-religious border crossing by 'cultural mediators' such as Ali Ufkî. Notably, Ali Ufkî's role as a mediator was not only between two cultures-the Greek-speaking subjects of the Ottoman Empire and the Ottoman literate elites-but also between members of different social backgrounds and statuses within the Greek Orthodox community, like the two folk songs sung for him and his relations with Panayiotis Nikousios.

17 Cem Behar, Mustkiden Müziğe. Osmanll/Türk Müziği: Gelenek ve Modernlik (Istanbul: YKY, 2015), 23-24. For the concept of cultural broker in this particular context, see Henk Driessen, "Mediterranean Divides and Connections: The Role of Dragomans as Cultural Brokers," in Agents of Transculturation: Border-crossers, Mediators, Go-betweens, ed. Sebastian Jobs and Gesa Mackenthun (Münster, New York, München, Berlin: Waxmann, 2013), 25-38.

18 For an annotated edition of the two folk songs and an analytical discussion on their possible sources and transmission, see Panagiotis

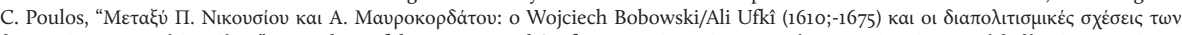

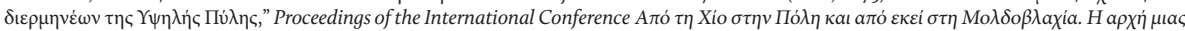

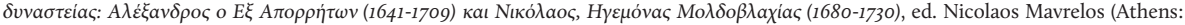
Gutenberg, forthcoming)

19 Tahir Sezan, Osmanlı Yer Adları (Alfabetik Sirayla) Yayın Nu. 21, T.C. Başbakanlık Devlet Arşivleri Genel Müdürlüğü, Ankara, 2006, p. 342. 20 Apart from the intriguing cross-cultural and spatial aspects of the abovementioned encounters, we should not underestimate their musical value. Although these two Greek folk songs are certainly exceptional with regard to their origin and quantity, the overall inclusion of folk material in Ali Ufkîs collections is important in the wider discussion of the historical processes in Ottoman music from the seventeenth century onwards. 
184 The examples discussed shed light on the internal division of given cultural domains-on the spaces within spaces. This might prove to be a useful analytical example in our attempt to study and make sense of musical intercommunal relations after the 'middle period,' that is, during the nineteenth and early twentieth centuries.

\section{Competing Modernities}

Until recently, the nineteenth century has been considered to be an abrupt breaking off in the tradition of Ottoman music and an era dominated by the westernization process implemented solely by the state. Recent historical scholarship challenges the background of these assumptions and argues convincingly towards a different direction. Firstly, the beginning of the process of modernization in the Ottoman Empire is situated rather earlier than the first half of the eighteenth century, and secondly much of the force of this process is attributed to internal social transformation rather than to external causes, like the West, for instance. ${ }^{21}$ Walter Feldman, both in his classical monograph Music of the Ottoman Court and in his recent research project, employs the notion of a "locally generated modernity," ${ }^{22}$ which, among other features, is also shaped by the rise of the presence of non-Muslim subjects in public service in the urban context. Under this conception, the 'long eighteenth century' extends until the mid-nineteenth century when Western-driven modernization started to indeed predominate the political scene directly affecting music.

Even after this turning point, however, the continuity of informal cultural institutions in certain domains of musical activity is often observed. For instance, although it is a fact that the court withdrew its support from the Eastern musical tradition, private musical gatherings established by networks that linked state bureaucrats, members of mystical orders (particularly the Mevlevi), and the few state-employed court musicians (musahip), seem to have been actively operating in Istanbul during the second half of the nineteenth century. ${ }^{23}$ New public open spaces, like gardens and parks hosting certain forms of musical sociality (e.g. Municipal Garden, Tepebaş1) ${ }^{24}$ continued the legacy of open leisure spaces (mesire) that flourished in the eighteenth century. Needless to say, the domain of nightclubs and entertainment-like the meyhane with which nineteenth-century Ottoman musical composition is strongly identified-also demonstrated impressive endurance in time.

Despite all kinds of continuities in forms of urban musical sociality and the lineages of intercommunal interaction briefly mentioned so far, there were features rooted in the early modern era that started to change. True as it may be, non-Muslim subjects who explored and experimented with aspects of modernity, such as printing and participation in volunteer associations, gained visibility and achieved more active engagement in the formation of the Ottoman public sphere. However, it seems that their engagement with modernity was in certain cases restricted within community limits addressing internal audiences. On top of that, the limits of the communities started to become less porous and flexible. When this engagement meant to be relevant to other communities, it often manifested in an antagonistic manner. This phenomenon seems to be grounded in a great divide of the new Ottoman middle class between Muslim and non-Muslim subjects that further reinforced the growth of nationalism within communities. ${ }^{25}$ Therefore, rather than considering intercommunal musical relations within the context of a single 'Ottoman modernity', it is more apt talking about "competing modernities"26 operating in parallel, both between the Ottoman state and the individual communities and among communities.

21 Abou-El-Haj, Formation of the Modern State, 86-89.

22 Feldman, Music of the Ottoman Court, 61. For a recently organized academic meeting on this topic visit

https://nyuad.nyu.edu/en/events/2018/february/a-locally-generated-modernity-the-ottoman-empire-in-the-long-18t.html,

accessed June 11, 2019.

23 Panagiotis C. Poulos, "At the House of Kemal: Private Musical Assemblies in Istanbul from the Late Ottoman Empire to the Turkish Republic," Theory and Practice in the Music of the Islamic World: Essays in Honour of Owen Wright, ed. Rachel Harris and Martin Stokes (London: Routledge, 2017), 109-110.

24 Öner, A Collective Biography, 131-333.

25 Bruce Masters, Christians and Jews in the Ottoman Arab World: The Roots of Sectarianism (Cambridge: Cambridge University Press 2004), 8.

26 Bjørn Thomassen, “Anthropology and its Many Modernities: When Concepts Matter," The Journal of the Royal Anthropological Institute

18, no. 1 (2012): 163-164. 


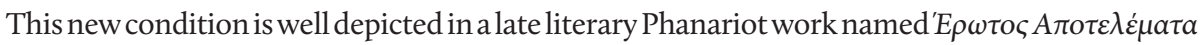
[The Consequences of Love], a collection of three short stories attributed to loannis Karatzas and Athanasios Psalidas published in Vienna in 1792, at the close of eighteenth century. This is an apt example in the current discussion of intercommunal musical relations and space because, in a way, it brought together those two features via a powerful element of Ottoman modernity, namely the printed book. The first love story is set in Istanbul, which is described as "...a city, between Asia and Europe, and a beautiful border of those two extraordinary and densely populated places of this world..." The hero, a young man by the name Çelebi Yorgaki, falls in love with a certain Elenintza, whom he acquainted in a bağçe (garden) in Psomathia (Samatya). In the first scene, Çelebi Yorgaki steps into a köşk (pavillion) and spontaneously composes a şarkl-like Phanariot song explaining his condition. Throughout the story, he addresses his beloved through many şarkı in Greek verse. Before each song he also announces the name of the makam in which the song was set to. The overall imagery of Istanbul and Samatya in particular in this story is built on elements of the Phanariot literary tradition that allude also to poetic conventions and themes of Ottoman lyrical poetry, such as the prominence of the garden. ${ }^{27}$ The open public space of the bağçe with kössk in its precincts, the high visibility of non-Muslims and the participation of female subjects in a type of public sociality that included musical performance can also be perceived as products of the aforementioned process of social and cultural transformation in the eighteenth century. However, as it has been rightly pointed out by Matthias Kappler that the image of Istanbul this narrative constructs is that of a Christian-inhabited city where "there are but a few signs of a surrounding or contiguous Islamic society, and Muslims are conspicuous only in their absence. ${ }^{{ }^{28}}$ This secluding appropriation of the city by the authors contrasts with the musical elements of the narrative which assumes a great degree of musical syncretism between the Greek Orthodox community and Ottoman urban music. The spontaneous composition and the performative manner of communication among the beloveds demonstrate this. In The Consequenses of Love, the urban space of Istanbul is used in an estranging manner in which musical performance marks out the borders of Greek Orthodox sociality. In this sense, this literary work can be seen as a transitional text that marks the passage between the "locally generated modernity" of the eighteenth century and the "competing modernities" of the nineteenth century.

The interchange of prose and verse and the autonomy of the corpus of the sited songs that are directly linked to the tradition of the handwritten mismagia, ${ }^{29}$ the Greek loan word for тестиа, makes this late-Phanariot literary work an intriguing 'predecessor' of the print song-text and music collections that would appear throughout the nineteenth century. Music publishing, as it appears, was the primary field where intercommunal antagonism manifested and "competing modernities" operated. The Ottoman musical 'printing age' was marked in the beginning of the nineteenth century by the pioneering publishing activity of the Greek Orthodox community. This activity was launched with the publication of the work by Chrysanthos of Madytos (ca. 1770-1846), a theoretical treatise presenting his proposal for the reform of the Byzantine notation system..$^{30}$ In 1830 the first collection of Ottoman urban songs, both in Greek and Turkish, in the reformed Byzantine notation system entitled Efterpi appeared in print, followed by a number of collections in a similar fashion. In 1852-1853, the first Turkish music song-text collection was published: the mecmua of Hacı Hüseyin Haşim Bey (1815-1868). ${ }^{31}$ Few years later, in 1858, the Armenian Aristakēs Yovhannēsean (1812-1878) published the first musical collection of Ottoman music using Western staff notation. ${ }^{32}$ The Armenian presence in music publishing was further enriched via the publication in the last quarter of the nineteenth century of collections using the Armenian reformed notation system known as "Hamparsum notation." 33

\footnotetext{
27 For a thorough comparison of the use of garden in the Phanariot literature and the Ottoman lyrical poetic tradition, see Matthias

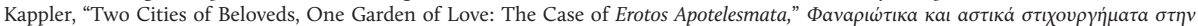

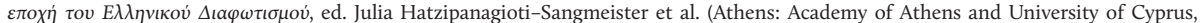
2013), 103-105.

28 lbid., 89, 90, 91.

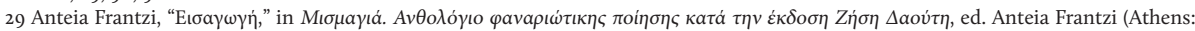
Estia, 1993[1818]), 29-30. On the transition from the handwritten to the print mismagia, see also Julia Hatzipanagioti-Sangmeister, "Old Tunes, New Tones: (Re-)Defining the "Phanariot Verses" of the Greek Enlightenment," The Historical Review/La Revue Historique 10 (2013): 170-171.

3o Katy Romanou, Great Theory of Music by Chrysanthos of Madytos (New Rochelle: The Axion Estin Foundation, 2010).

31 Hâsim Bey, Mecmû́ầ- kârhâ ve nakıshâ ve şarkıyât, (Dersaadet [Istanbul], 1269/1852-1853).

32 Olley, Writing Music in Nineteenth-Century Istanbul, 85.

33 Ibid., 126
} 
186 The above mentioned illustrative parallel publications point to an interesting pattern of interaction mixed with elements of cultural and political rivalry between the different communities that continued until the beginning of the twentieth century. Preliminary comparison shows that collections like those mentioned demonstrated patterns of material copying and borrowing as well as significant exclusions and points of diversion. ${ }^{34} \mathrm{~A}$ closer examination of the makeup of these collections reveals the musical networks which formed in Istanbul throughout the nineteenth century that linked the musical environment of Turkish musicians with that of the musicians of the Greek, Armenian, and Jewish communities, which also sheds light on the spatial transformation of intercommunal interaction.

A demonstrative comparative example of parallelisms and interrelations can be seen between Haşim Bey's meстиa and the musical collection of Ioannis Zographos (from Geyve) entitled

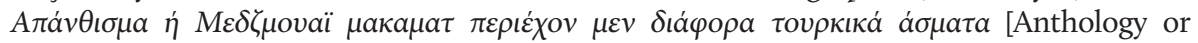
mecmua-ı makamat, including also various Turkish songs] published in $1857.3^{35}$ Notably, second editions of both collections appeared in 1864 and 1872, respectively. In the prologue of the first edition, Zographos states that since 1851 he had started learning "this Music" via a certain mastersinger of secular music (exoterikos [external] chanendes / hanende) serving the Ottoman palace. Although he does not directly name his teacher, he does borrow material and acknowledges Haşim Bey's collection. ${ }^{36}$ Further comparison between the two collections and their second editions gives indications about who might have been Zographos's teacher, as he repeatedly stresses those who were court singers in the second edition by noting on the

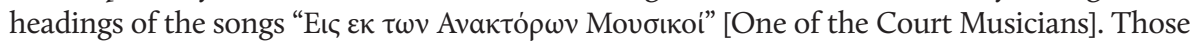
composers were Lâtif Ağa (1815?-1885?), Ser-Müezzin Mîralay Rif'at Bey (1820-1888), and the Armenian Nikoğos (1820-1890). The musical transmission network between the court musicians and loannis Zographos should be placed within the domain of private musical gatherings of the mid-nineteenth century. Whether this suggests that Greek musicians frequented the well-established Muslim house gatherings or that a parallel independent form of private tuition between Muslim, Armenian, and Greek Orthodox musicians existed in Istanbul requires further research. ${ }^{37}$ In any case, this is proof of the endurance in the second half of the nineteenth century of intercommunal musical activity in the city and the loose yet existing ties between those urban spaces and the Court. However, the boundaries of these spaces were ever-changing. At those times the intercommunal boundaries which became evident were now shrinking, losing also their previous permeability.

Given that loannis Zographos had access to Haşim Bey's mecmua, what is even more interesting in terms of the quality of intercommunal relations is what he did not include in his collection. It is notable for instance that although the collection contains compositions by Armenian musicians, it does not include compositions by Jewish musicians. It is only in the second edition of his mecmua in 1872 that we get a single piece by the celebrated Jewish composer Tanburi İsak. ${ }^{38}$ The field of print musical collections was indeed a manifestation of "competing modernities." The various anthology traditions are in conversation with each other, only that their conversation was antagonistic. Indicative of the dynamics of this rivalry is that in the prologue of the second edition of his mecmuas in 1872, Zographos omits altogether the praise of the art of the "courtly singers." Instead, he reverses the praise to the ancient routes of music, a fact, as he claims, also acknowledged by the "Arabs and Ottomans." Through this argumentation, Ioannis Zographos appropriates the Eastern musical tradition and indirectly attributes it to the Greek Nation. ${ }^{39}$

While chronologically approaching the beginning of the twentieth century, the boundaries of ethnic identities are manifested in a more consolidated form, and Zographos' change of

34 For a preliminary comparison of the Greek musical collections and important remarks concerning their content and lines of transmission, see Cem Behar, Musıkiden Müziğe, 244-268.

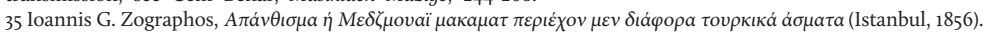

$36 \mathrm{In}$ fact, both in the first and the second editions of his collection, Zographos reproduces a theoretical section on rhythmic cycle from Hasim Bey's mecmua as an introductory guide to the notated pieces.

37 For a reference to non-Muslim musical house gatherings in Istanbul, see Balıkhane Nazırı Ali Rıza Bey, Eski Zamanlarda Istanbul Hayatı, ed. Ali Şükrü Çoruk (Istanbul: Kitabevi, 2001), 175 .

38 For a critical remark on the issue of the Greek-Jewish musical relations and the possible lines of repertoire transmission and interaction, see Behar, Mustkiden Müziğe, 265 .

39 For the ideological debate on music and its origins in the Greek Orthodox community of Istanbul, see Merih Erol, Greek Orthodox Music in Ottoman Istanbul: Nation and Community in the Era of Reform (Bloomington: Indiana University Press), 2015. 
stance obviously reflects that. In this sense, it is as if he started inhabiting the Istanbul of The Consequences of Love, estranging himself from intercommunal qualities of his apprenticeship and consequently from the repertoire of his musical collections. However, one should be careful about who the appropriators of this fairly segregating imagery of the city are each time. The kind of static and idyllic urban imagery of Samatya in The Consequences of Love contrasts with descriptions of its social life in the second half of the nineteenth century. The Greek doctor Alexandros Paspatis is explicit about the deafening shouts in the meyhane establishments of Samatya, especially after Lent and during Easter celebrations. ${ }^{40}$ Similarly, in his topographical survey of Istanbul, Skarlatos Vyzantios, a Greek intellectual and contemporary of Alexandros Paspatis, adds the neighborhood of Vlanga (Langa) into the entertainment scene of the southern city-wall area by reporting " $8-10$ coffee places built by the sea" that frequently hosted musical ensembles. ${ }^{41}$ Interestingly, Vyzantios also mentions performances of meddah in these places breaking the Christian representation of the abovementioned authors. One should not forget at this point that both Vlanga and Samatya were bordering the Kasap llyas neighbourhood, which was populated mostly by Muslims. ${ }^{42}$ In any case, the abovementioned descriptions point to the domain of the professional performers.

\section{The Professional Performers of the Parish of Stavrodromi (Beyoğlu)}

While the network of Muslim and non-Muslim learned musicians, or better, musicians of a higher social status, gradually faded out, a parallel network of nightclub musicians seems to have endured if not flourished. The nightclub musicians of late Ottoman Istanbul have been a kind of topos in nostalgic narratives about city life. However, a proper historical study on this professional group of particular inter-confessional character is still missing. The lack of such research is due to, among other reasons, the sparseness of historical documentation on the lives of these musicians. ${ }^{43}$ Particularly in the case of non-Muslim musicians, access to community archives might have been restricted or in certain cases, prohibited. This gap has been partly covered by secondary sources, such as the contemporary press, through which one gets a broad picture of the prominent professional incesaz ensembles operating in the nightclubs of the city. ${ }^{44}$ An indicative example of the ethno-religious makeup of these types of ensembles is that which was led by the celebrated Armenian violinist and composer Kemanî Tatyos (1858-1913), consisting of a Muslim, kanunî Şemsî (1850?-1922?), the Armenian hanende, Boğos (1872-1945), and Karakaş Efendi (?-1920?), who was Jewish. This particular ensemble performed in 1896 in Çırçır Suyu in Istanbul.45

The parallel domains of musical activity represented by loannis Zographos and the circle of court musicians and that by Kemanî Tatyos and his fellow musicians foreground a composite image of intercommunal musical networks of Istanbul in the second half of the nineteenth century. The extent to which these domains correspond to delineated spaces in the city is a matter of further enquiry as well as the matter of the possible overlaps and connecting points of the two ${ }^{46}$ This composite image is based on the internal social and cultural stratification that, as already seen in the case of Ali Ufkî, is a crucial element in understanding the pluralism of Ottoman urban musical tradition. Shifting the focus of the enquiry on space in this case reveals a privileged viewpoint for the study of intercommunal relations.

In particular, the parish registers of Stavrodromi-the official Greek name of the central Christian Orthodox parish in Beyoğlu-dated possibly to the beginning of the twentieth century, give a very interesting picture of the patterns of spatial distribution of professional musicians within the topographical limits of the community (fig. 1). Professional musicians, working presumably in nightclubs or taverns (meyhane), are registered under the label

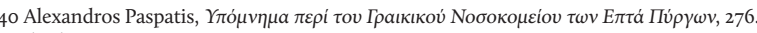

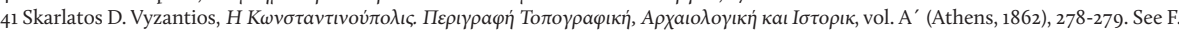
Melike Sümertaş's review essay in this issue on the 2019 edition of Vyzantios/Byzantios' book.

42 Cem Behar, A Neighborhood in Ottoman Istanbul: Fruit Vendors and Civil Servants in the Kasap ilyas Mahalle (Albany: State University of New York Press, 2003).

43 Öner, A Collective Biography, 19, 143.

44 Ruhi Kalender, "Yüzyılımızın Başlarında Istanbul'un Musiki Hayatı" AÜIFD 23 (1978): 411-444.

45 Ibid., 144 .

46 Onur Öner's recently completed doctoral dissertation addresses these kinds of research questions. 


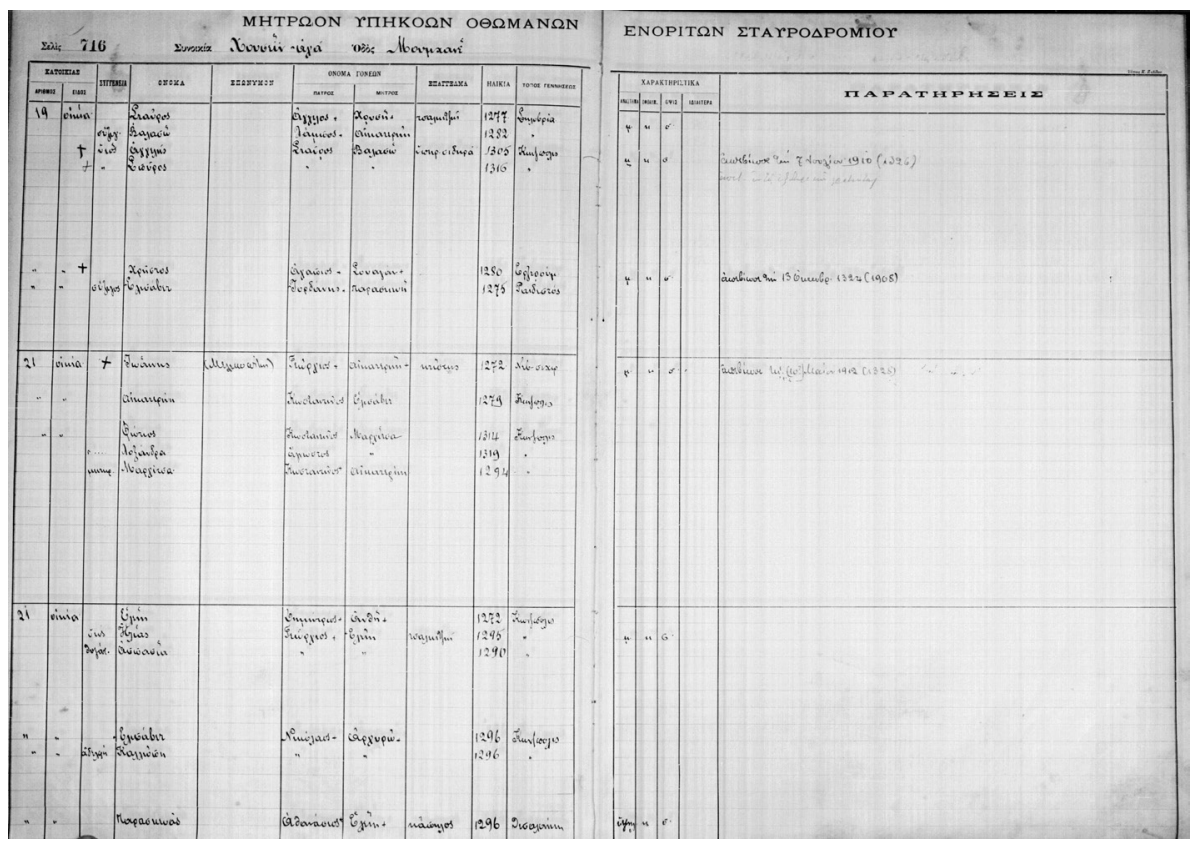

Figure 1: Registry of Ottoman Citizens of the Parish of Stavrovromi $(\Theta 2,733$, Anthemion, NKUA).

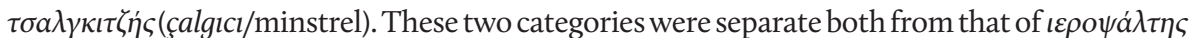

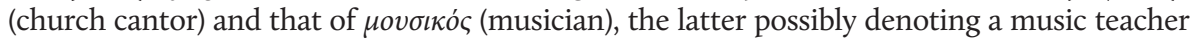
of Western music. Notably, there is a fourth category of music profession which is the street musicians playing music box, namely the $\lambda \alpha \tau \varepsilon \rho v \alpha \tau \zeta \eta^{\prime} \varsigma$ (laternacı/barrel organ player).

Overall there are twenty professional musicians registered in the parish records of Stavrodromi (table 1). The first remarkable feature is that except from the case of Lambros Bacanos, who can safely be identified due to additional family details included in the entry, the majority of the rest do not correspond to any of the well-known Greek Orthodox musicians of that time. Consequently, the group of professional performers from the Greek Orthodox community is not restricted to certain musicians whose fame probably is related to the fact that they were also prolific composers (e.g. Nikolaki Efendi). In addition, this group appears to be much larger than it was thought to be. A second remark concerns the fact that the residential choice of those musicians is identified with the physical domain of their profession. Again, one cannot definitely argue that each of these musicians worked in the nightclubs and meyhane establishments of Beyoğlu. However, the high number of such places in this particular district of Istanbul makes it a strong case. This leads to a further remark regarding the housing pattern of this group. The vast majority of professional performers resided in the neighborhood (mahalle) of Hüseyin Ağa (table 2). ${ }^{47}$ The registry records seventeen performers residing in the district, nine of whom were compatriots from the region of Silivri and nearby Çatalca outside Istanbul. Interestingly seven of them, together with three fellow musicians from Istanbul, resided on a single street (sokak), namely Mumhane, which seems to be a street where many musicians lived at that time..$^{8}$ Notably, this is the street where the legendary Bacanos family resided (fig. 2). This account confirms a housing pattern based on the common place of origin and profession. ${ }^{49}$ This is

47 The geographical limits of the Greek community that the registry reflects points presumably to the parish's 1904 regulation, according

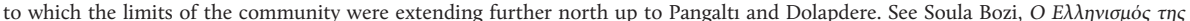

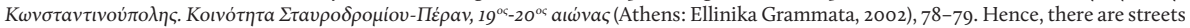
appearing as belonging to certain neighbourhoods but are located far out of their standard limits.

48 Based on the previous note and on further evidence related to the street layout within the registry, Mumhane Sokak, which in the registry appears to belong to the Hüseyin Ağa neighborhood, is most possibly identified with Mumhane Sokak in Tatavla (nowadays Küçük Mumhane Sokak in Kocatepe/Beyoğlu), Jacques Pervititch Sigorta Haritalarında Istanbul / Istanbul in the Insurance Maps of Jacques Pervititch (Istanbul: Axa Oyak-Tarih Vakf1 Yayınları, 200o), 82.

49 For a study on the demography of the Hüseyin Ağa neighborhood in Beyoğlu in the late Ottoman period and particularly on the impact of immigration from various places of the Empire and of Greece on the established household patterns of the Greek community, see Meropi Anastassiadou, "Greek-Orthodox Households in Istanbul (19th-2oth Centuries): Social and Demographic Trends," in Economy and Society in Both Shores of the Aegean, ed. Lorans Tanatar Baruh and Vangelis Kechriotis (Athens: Alpha Bank Historical Archives, 2010), 420 . 


\begin{tabular}{|l|l|l|l|l|}
\hline \multicolumn{1}{|c|}{ Name } & Father's name & Date of birth $^{\text {50 }}$ & Place of birth $^{51}$ & Neighbourhood \\
\hline $\begin{array}{l}\text { Charalambos } \\
\text { (Lambros) }\end{array}$ & Grigorios & 1278 & Silivri & Hüseyin Ağa \\
\hline Giovanakis & Grigorios & 1296 & Silivri & Hüseyin Ağa \\
\hline Stavros & Angelos & 1277 & Silivri & Hüseyin Ağa \\
\hline Elias & Georgios & 1295 & Istanbul & Hüseyin Ağa \\
\hline Dimitrios & Ephstratios & 1300 & Silivri & Hüseyin Ağa \\
\hline Constantinos & Nikolaos & 1262 & Çatalca & Hüseyin Ağa \\
\hline Nikolaos & loannis & 1287 & Istanbul & Hüseyin Ağa \\
\hline Evangelos & Ipsilantis & 1298 & Silivri & Hüseyin Ağa \\
\hline Nikolaos & Theodoros & 1296 & Istanbul & Hüseyin Ağa \\
\hline Diamantis & Constantinos & 1281 & Silivri & Hüseyin Ağa \\
\hline Giorgos & Stephanos & 1278 & Silivri & Hüseyin Ağa \\
\hline Charalambos & Emmanouil & 1292 & Istanbul & Hüseyin Ağa \\
\hline Stavros & Vasilios & 1280 & Istanbul & Hüseyin Ağa \\
\hline Dimitrios & Aslanis & 1261 & Bursa & Hüseyin Ağa \\
\hline Sotirios & Dimitrios & 1292 & Istanbul & Hüseyin Ağa \\
\hline Alexis & Kostis & 1273 & Silivri & Hüseyin Ağa \\
\hline Themistoklis & Kostis & 1278 & Istanbul & Kamer Hatun \\
\hline Charalambos & Emmanouil & 1292 & Istanbul & Kamer Hatun \\
\hline loannis & Georgios & 1303 & Istanbul & Tomtom \\
\hline Moschos & Argirakis & 1306 & Istanbul & Tomtom \\
\hline & & & & \\
\hline & & & 129 & \\
\hline
\end{tabular}

Table 1: Professional Performers in the Parish Registry of Stavrodromi

\begin{tabular}{|c|l|l|l|l|}
\hline House No. & Name & Father's name & Date of Birth & Place of birth \\
\hline 15 & $\begin{array}{c}\text { Charalambos } \\
\text { (Lambros) }\end{array}$ & Grigorios & 1278 & Silivri \\
\hline 15 & Giovanakis & Grigorios & 1296 & Silivri \\
\hline 19 & Stavro & Angelos & 1277 & Silivri \\
\hline 21 & Elias & Georgios & 1295 & Istanbul \\
\hline 22 & Dimitrios & Ephstratios & 1300 & Silivri \\
\hline 22 & Constantinos & Nikolaos & 1262 & Çatalca \\
\hline 22 & Nikoloas & loannis & 1287 & Istanbul \\
\hline 23 & Evangelos & Iplilantis & 1298 & Silivri \\
\hline 45 & Nikoloas & Theodoros & 1296 & Istanbul \\
\hline 54 & Diamantis & Constantinos & 1281 & Silivri \\
\hline
\end{tabular}

Table 2: Professional Performers on Mumhane Street 


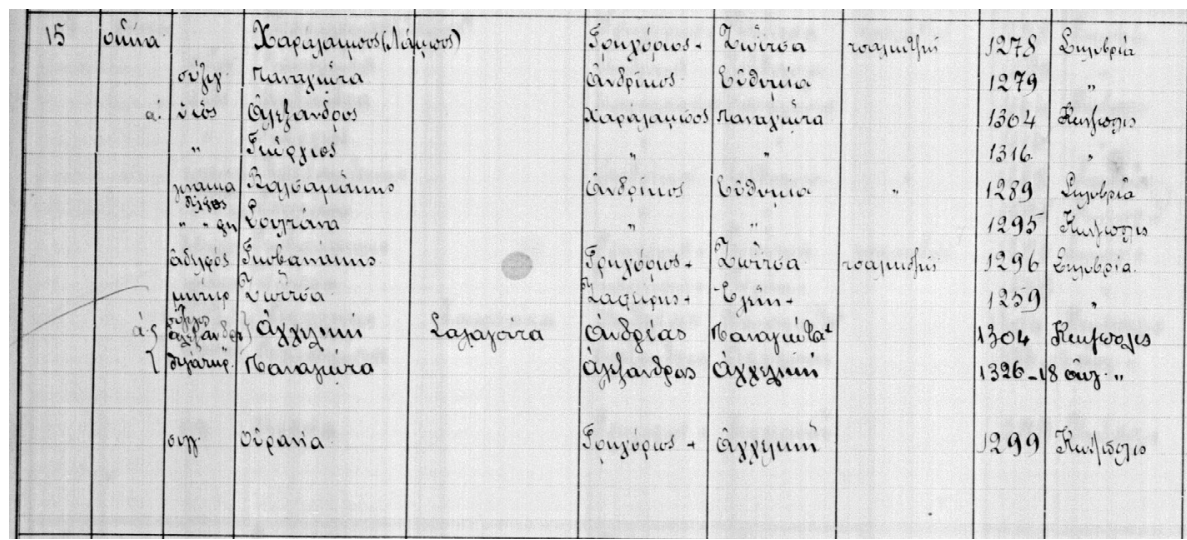

also an example of an extended family housing professional performers. The two musician brothers, Lambros and Grigoris, lived in the same house with their families and were both registered under the profession of tsalgitzi. Lambros' children, Yorgo and Aleko, were also registered in the same entry, yet without any indication of profession, possibly due to their young age at the time of the completion of the entry.52

Obviously, the domain of Istanbul's professional nightclub performers was renewed during the second half of the nineteenth century via immigrants from nearby provinces of Istanbul. All immigrant musicians were born between $1845^{-1884}$, so they possibly moved to Istanbul sometime within the second half of the nineteenth century onwards. The itineraries of these 'newcomers' to Istanbul reminds us that Ottoman urban music was not a demographically static field, and this feature, in a sense, is a strong element of continuity between the seventeenth century and the late Ottoman era. A further consequence of this feature is that despite variations in quality and intensity, musical performance always sustained intercommunal interaction. This is a case where musical performance transforms space. In a way, although the housing patterns of the professional musicians of the Greek Orthodox parish of Stavrodromi were neatly placed within the boundaries of their community, they were able to challenge the rigidness imposed by "competing modernities" through their participation in the professional intercommunal spaces of entertainment located in the broader area of Beyoğlu.

\section{In Conclusion: Intermediary Musical Spaces}

The overall aim of this article has been to address those understated intermediary spaces that were produced in the context of musical interaction among the various communities residing in Istanbul in the Ottoman era. The underpinning theme in defining those spaces and tracing their dynamic trajectory throughout the history of the city has been the quest for voicing the diverse elements that composed them. This task has shown that the internal stratification of communities was often quite more multifaceted than previously thought and that the subsequent layers are not always easily traceable. As demonstrated, the internal diversity of communities was based both on the cultural and the social background of its members. Moreover, the makeup of each community and its musicians was constantly renewed through immigration. A consequent challenging question that needs to be addressed is whether and how this diversity was expressed in musical terms.

The Greek Orthodox community registry presented in the last section can obviously fill in certain gaps in the history of professional musicianship in late Ottoman period. Still though, the image that one gets even in the case of such precious and understudied sources is far from being a complete one. Ideally, writing the history of these intermediary spaces requires the comparative study of similar archival material from all communities.
Figure 2: The Extended Bacanos Family $(\Theta 2,733$, Anthemion, NKUA).

52 This example of potentially subsequent generations of professional musicians (father-son) points to the need for a more careful examination of the overall list of the musicians and their fathers (fig. 1) in order to identify cases of known musicians from other sources. 
It is through this comparison that the intermediary spaces of musical interaction will be properly defined and located in the city. The history of those spaces bares elements from the life stories of everyday musicians.

Finally, this article argues that the spatial dimension of music making not only reinforced and sustained cultural distinctions but also forged ties between different social groups and ethno-religious communities that were mutually responding to the challenges of Ottoman modernity. A crucial point in this trajectory was the transition from the "locally generated modernity" of the long eighteenth century to the "competing modernities" of the later era. An overall revisit of Ottoman music history through the analytical tool of space could possibly contribute to our understanding of this transition and its impact on music. 